Supporting Information

\title{
A 9.16\% power conversion efficiency organic solar cell with a porphyrin conjugated polymer using a non-fullerene acceptor
}

\author{
Loïc Tanguy ${ }^{\dagger}$, Prateek Malhotra ${ }^{\ddagger}$, Surya Prakash Singh ${ }^{\circ}$, Gessie Brisard ${ }^{\dagger}$, Ganesh D. \\ Sharma ${ }^{* *}$ and Pierre D. Harvey ${ }^{\dagger *}$. \\ ${ }^{\dagger}$ Department of chemistry, University of Sherbrooke, 2500 bd de l'Université, Sherbrooke, QC, J1K 2R1, Canada \\ ${ }^{\ddagger}$ Department of Physics, LNM Iinstitute of Information Technology (Deemed to be University), Jamdoli 302017 Jaipur, India \\ opolymers and Functional Materials Division, CSIR-Indian Institute of Chemical Technology, Uppal road, Tarnaka, Hyderabad- \\ 500007, India
}

*E-mail: Pierre.D.Harvey@usherbrooke.ca (Prof. Pierre D. Harvey)

*E-mail: gdsharma273@gmail.com (Prof. Ganesh D. Sharma) 


\section{Table of contents}

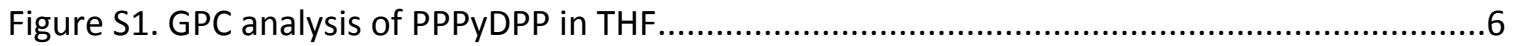

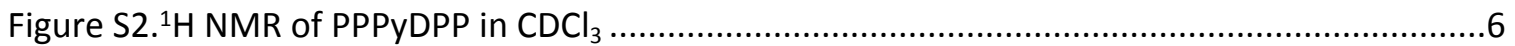

Figure S3. Geometry optimization of PPyP (by DFT) using a THF solvent field.............................

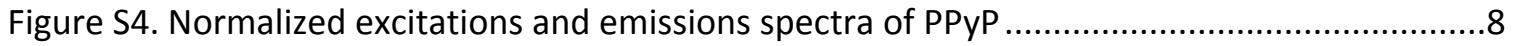

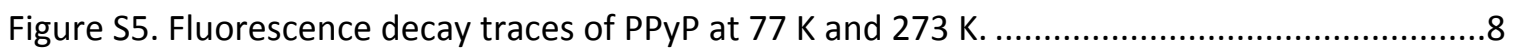

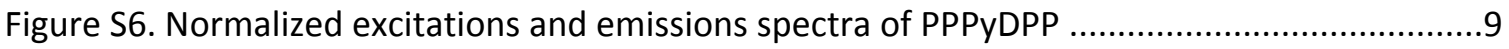

Figure S7. Fluorescence decay traces of PPPyDPP at 77K and 273K ..........................................

\section{Caracterizations}

Figure S8. Cyclic voltammogram of PPPyDPP measured at $200 \mathrm{mV} / \mathrm{s}$ in acetonitrile.................11

Figure S9. Cyclic voltammogram of PPyP measured at $100 \mathrm{mV} / \mathrm{s}$ in dichloromethane................12

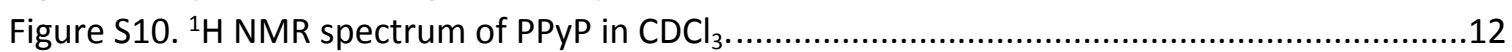

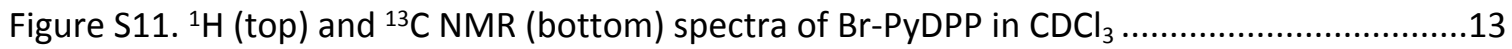

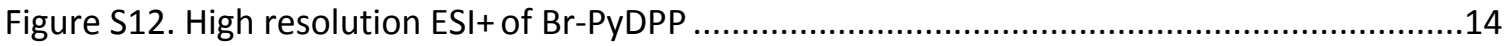

Figure S13. ${ }^{1} \mathrm{H}$ NMR spectrum of zinc(II)(5,15-bis[3,4,5-tris(2-butyloctyloxy)phenyl]-10,20-

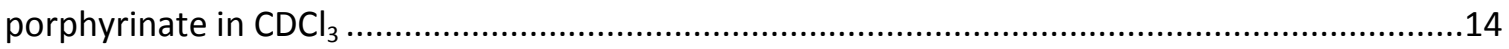

Figure S14. ${ }^{13} \mathrm{C}$ NMR (DEPT135) analysis of zinc(II)(5,15-bis[3,4,5-tris(2-butyloctyloxy)phenyl]-

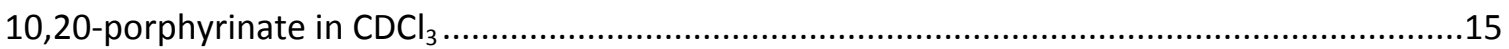

Figure S15. High resolution ESI+ of zinc(II)(5,15-bis[3,4,5-tris(2-butyloctyloxy)phenyl]-10,20-

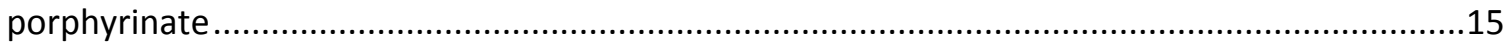

Figure S16. ${ }^{1} \mathrm{H}$ NMR spectrum of zinc(II)(10-iodo-5,15-bis[3,4,5-tris(2-butyloctyloxy)phenyl]-20-

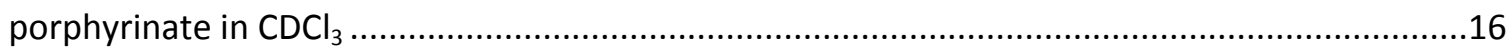

Figure S17. ${ }^{13} \mathrm{C}$ NMR spectrum of zinc(II)(10-iodo-5,15-bis[3,4,5-tris(2-butyloctyloxy)phenyl]-20-

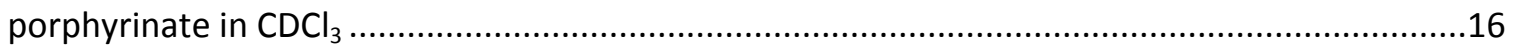

Figure S18. High resolution ESI+ of zinc(II)(10-iodo-5,15-bis[3,4,5-tris(2-butyloctyloxy)phenyl]-20-

porphyrinate

Figure S19. ${ }^{1} \mathrm{H}$ NMR spectrum of zinc(II)(10-[(trimethylsilyl)ethynyl]-5,15-bis[3,4,5-tris(2-

butyloctyloxy)phenyl]-20-porphyrinate in $\mathrm{CDCl}_{3}$

Figure S20. ${ }^{13} \mathrm{C}$ NMR analysis of zinc(II)(10-[(trimethylsilyl)ethynyl]-5,15-bis[3,4,5-tris(2-

butyloctyloxy)phenyl]-20-porphyrinate in $\mathrm{CDCl}_{3}$

Figure S21. High resolution ESI+ of zinc(II)(10-iodo-5,15-bis[3,4,5-tris(2-butyloctyloxy)phenyl]-20porphyrinate

Table S1. List of publications and patents where the synthesis of PyDPP and its derivatives were found. 
Table S1. List of publications and patents where the synthesis of PyDPP and its derivatives was reported.

\begin{tabular}{|c|c|}
\hline Entry & References \\
\hline 1 & $\begin{array}{l}\text { Li, M.; Zhang, G.; Xiong, L.; Zhu, M.; Pei, Y.; Peng, Q.; Liu, Y. Adjusted Photovoltaic Performance of } \\
\text { Tetrafluorobenzene-Based Small Molecules by Tailoring with Different Arm of Acceptor Units. Dye. Pigment. } \\
\text { 2018, 158, 402-411. https://doi.org/10.1016/j.dyepig.2018.05.067. }\end{array}$ \\
\hline 2 & $\begin{array}{l}\text { Mueller, C. J.; Gann, E.; Singh, C. R.; Thelakkat, M.; McNeill, C. R. Control of Molecular Orientation in } \\
\text { Polydiketopyrrolopyrrole Copolymers via Diffusive Noncovalent Interactions. Chem. Mater. 2016, } 28 \text { (19), } \\
\text { 7088-7097. https://doi.org/10.1021/acs.chemmater.6b03245. }\end{array}$ \\
\hline 3 & $\begin{array}{l}\text { Li, P.; Xu, L.; Shen, H.; Duan, X.; Zhang, J.; Wei, Z.; Yi, Z.; Di, C.; Wang, S. D-A 1 -D-A } 2 \text { Copolymer Based on } \\
\text { Pyridine-Capped Diketopyrrolopyrrole with Fluorinated Benzothiadiazole for High-Performance Ambipolar } \\
\text { Organic Thin-Film Transistors. ACS Appl. Mater. Interfaces 2016, 8 (13), 8620-8626. } \\
\text { https://doi.org/10.1021/acsami.5b12050. }\end{array}$ \\
\hline 4 & $\begin{array}{l}\text { Hendriks, K. H.; Wijpkema, A. S. G.; van Franeker, J. J.; Wienk, M. M.; Janssen, R. A. J. Dichotomous Role of } \\
\text { Exciting the Donor or the Acceptor on Charge Generation in Organic Solar Cells. J. Am. Chem. Soc. 2016, } 138 \\
\text { (31), 10026-10031. https://doi.org/10.1021/jacs.6b05868. }\end{array}$ \\
\hline 5 & $\begin{array}{l}\text { Guo, K.; Bai, J.; Jiang, Y.; Wang, Z.; Sui, Y.; Deng, Y.; Han, Y.; Tian, H.; Geng, Y. Diketopyrrolopyrrole-Based } \\
\text { Conjugated Polymers Synthesized via Direct Arylation Polycondensation for High Mobility Pure n-Channel } \\
\text { Organic Field-Effect Transistors. Adv. Funct. Mater. 2018, } 28 \text { (31), } 1801097 . \\
\text { https://doi.org/10.1002/adfm.201801097. }\end{array}$ \\
\hline 6 & $\begin{array}{l}\text { Tamano, M.; Chisaka, J.; Watanabe, M. Diketopyrrolopyrrole-Type Material, Ink Composition Containing It, } \\
\text { and Organic Thin Film Solar Cell. 2014075441, } 2014 .\end{array}$ \\
\hline 7 & $\begin{array}{l}\text { Mueller, C. J.; Singh, C. R.; Thelakkat, M. EDOT-Diketopyrrolopyrrole Copolymers for High Bulk Hole Mobility } \\
\text { and near Infrared Absorption. J. Polym. Sci. Part B Polym. Phys. 2016, } 54 \text { (6), 639-648. } \\
\text { https://doi.org/10.1002/polb.23955. }\end{array}$ \\
\hline 8 & $\begin{array}{l}\text { Wang, X.; Miao, X.; Ying, L.; Deng, W.; Cao, Y. Effect of Pyridyl Orientation on the Molecular Conformation } \\
\text { and Self-Assembled Morphology of Regioisomeric Diketopyrrolopyrrole Derivatives. J. Phys. Chem. C 2017, } \\
121 \text { (35), 19305-19313. https://doi.org/10.1021/acs.jpcc.7b06511. }\end{array}$ \\
\hline 9 & $\begin{array}{l}\text { Yue, J.; Liang, J.; Sun, S.; Zhong, W.; Lan, L.; Ying, L.; Yang, W.; Cao, Y. Effects of Flanked Units on } \\
\text { Optoelectronic Properties of Diketopyrrolopyrrole Based } \pi \text {-Conjugated Polymers. Dye. Pigment. 2015, 123, } \\
\text { 64-71. https://doi.org/10.1016/j.dyepig.2015.07.021. }\end{array}$ \\
\hline 10 & $\begin{array}{l}\text { Yue, J.; Sun, S.; Liang, J.; Zhong, W.; Lan, L.; Ying, L.; Huang, F.; Yang, W.; Cao, Y. Effects of Pyridyl Group } \\
\text { Orientations on the Optoelectronic Properties of Regio-Isomeric Diketopyrrolopyrrole Based } \pi \text {-Conjugated } \\
\text { Polymers. J. Mater. Chem. C 2016, } 4 \text { (13), 2470-2479. https://doi.org/10.1039/C6TC00051G. }\end{array}$ \\
\hline 11 & $\begin{array}{l}\text { Yang, C.-Y.; Jin, W.-L.; Wang, J.; Ding, Y.-F.; Nong, S.; Shi, K.; Lu, Y.; Dai, Y.-Z.; Zhuang, F.-D.; Lei, T.; et al. } \\
\text { Enhancing the N-Type Conductivity and Thermoelectric Performance of Donor-Acceptor Copolymers } \\
\text { through Donor Engineering. Adv. Mater. 2018, } 30 \text { (43), 1802850. https://doi.org/10.1002/adma.201802850. }\end{array}$ \\
\hline 12 & Yamamoto, H.; Dan, N. Fluorescent Diketopyrrolopyrroles. 2004090046, 2004. \\
\hline 13 & $\begin{array}{l}\text { Mueller, C. J.; Singh, C. R.; Fried, M.; Huettner, S.; Thelakkat, M. High Bulk Electron Mobility } \\
\text { Diketopyrrolopyrrole Copolymers with Perfluorothiophene. Adv. Funct. Mater. 2015, } 25 \text { (18), 2725-2736. } \\
\text { https://doi.org/10.1002/adfm.201404540. }\end{array}$ \\
\hline
\end{tabular}




\begin{tabular}{|c|c|}
\hline 14 & $\begin{array}{l}\text { Li, Z.; Xu, X.; Zhang, W.; Genene, Z.; Mammo, W.; Yartsev, A.; Andersson, M. R.; Janssen, R. A. J.; Wang, E. } \\
\text { High-Photovoltage All-Polymer Solar Cells Based on a Diketopyrrolopyrrole-isoindigo Acceptor Polymer. J. } \\
\text { Mater. Chem. A 2017, } 5 \text { (23), 11693-11700. https://doi.org/10.1039/C6TA09379E. }\end{array}$ \\
\hline 15 & $\begin{array}{l}\text { Purc, A.; Banasiewicz, M.; Glodkowska-Mrowka, E.; Gryko, D. T. Modulation of the Fluorescence Properties } \\
\text { of Diketopyrrolopyrroles via Various Electron-Rich Substituents. J. Mater. Chem. C 2016, } 4 \text { (14), 2877-2885. } \\
\text { https://doi.org/10.1039/C5TC03190G. }\end{array}$ \\
\hline 16 & $\begin{array}{l}\text { Sui, Y.; Deng, Y.; Han, Y.; Zhang, J.; Hu, W.; Geng, Y. N-Type Conjugated Polymers Based on 3,3'-Dicyano- } \\
\text { 2,2'-Bithiophene: Synthesis and Semiconducting Properties. J. Mater. Chem. C 2018, } 6 \text { (47), 12896-12903. } \\
\text { https://doi.org/10.1039/C8TC03725F. }\end{array}$ \\
\hline 17 & $\begin{array}{l}\text { Chisaka, J.; Hatemata, A.; Tamano, M. Power Storage Material, Power Storage Device Electrode, and Power } \\
\text { Storage Device. 2016091751, } 2016 .\end{array}$ \\
\hline 18 & $\begin{array}{l}\text { Yu, G.; Gao, D.; Chen, Z.; Zhang, W. Preparation and Characterization of Pyridinothiene Containing Polymer } \\
\text { Compounds as Semiconductor Materials. 106632410, } 2017 .\end{array}$ \\
\hline 19 & $\begin{array}{l}\text { Yang, W.; Yue, J.; Wu, H.; Peng, J.; Cao, Y. Preparation of Pyrrolopyrrolidone Units-Containing Monomer and } \\
\text { Polymer for Use in Solar Cells. 105061435, } 2015 .\end{array}$ \\
\hline 20 & $\begin{array}{l}\text { Ni, Z.; Dong, H.; Wang, H.; Ding, S.; Zou, Y.; Zhao, Q.; Zhen, Y.; Liu, F.; Jiang, L.; Hu, W. Quinoline-Flanked } \\
\text { Diketopyrrolopyrrole Copolymers Breaking through Electron Mobility over } 6 \text { Cm } 2 \text { V -1 s }-1 \text { in Flexible Thin } \\
\text { Film Devices. Adv. Mater. 2018, } 30 \text { (10), 1704843. https://doi.org/10.1002/adma.201704843. }\end{array}$ \\
\hline 21 & $\begin{array}{l}\text { Cann, J. R.; Cabanetos, C.; Welch, G. C. Spectroscopic Engineering toward Near-Infrared Absorption of } \\
\text { Materials Containing Perylene Diimide. Chempluschem 2017, } 82 \text { (11), 1359-1364. } \\
\text { https://doi.org/10.1002/cplu.201700502. }\end{array}$ \\
\hline 22 & $\begin{array}{l}\text { Song, H.-S.; Ahn, S. K.; Karthikeyan, N. S.; Gal, Y.-S.; Jin, S.-H.; Lee, J. W. Study on Low-Band Gap Polymers } \\
\text { Based on Diketopyrrolopyrrole for Organic Photovoltaic Applications. Mol. Cryst. Liq. Cryst. 2013, } 578 \text { (1), } \\
\text { 55-62. https://doi.org/10.1080/15421406.2013.804371. }\end{array}$ \\
\hline 23 & $\begin{array}{l}\text { Kuwabara, J.; Takase, N.; Yasuda, T.; Kanbara, T. Synthesis of Conjugated Polymers Possessing } \\
\text { Diketopyrrolopyrrole Units Bearing Phenyl, Pyridyl, and Thiazolyl Groups by Direct Arylation } \\
\text { Polycondensation: Effects of Aromatic Groups in DPP on Physical Properties. J. Polym. Sci. Part A Polym. } \\
\text { Chem. 2016, } 54 \text { (15), 2337-2345. https://doi.org/10.1002/pola.28105. }\end{array}$ \\
\hline 24 & $\begin{array}{l}\text { Jung, J. W.; Liu, F.; Russell, T. P.; Jo, W. H. Synthesis of Pyridine-Capped Diketopyrrolopyrrole and Its Use as } \\
\text { a Building Block of Low Band-Gap Polymers for Efficient Polymer Solar Cells. Chem. Commun. 2013, } 49 \text { (76), } \\
\text { 8495. https://doi.org/10.1039/c3cc44676j. }\end{array}$ \\
\hline 25 & $\begin{array}{l}\text { Vakuliuk, O.; Purc, A.; Clermont, G.; Blanchard-Desce, M.; Gryko, D. T. The Impact of the Interplay between } \\
\text { Steric and Electronic Effects on the Synthesis and Optical Properties of Diketopyrrolopyrroles Bearing } \\
\text { Pyridine Moieties. ChemPhotoChem 2017, } 1 \text { (5), 243-252. https://doi.org/10.1002/cptc.201600047. }\end{array}$ \\
\hline 26 & $\begin{array}{l}\text { Buckley, C.; Thomas, S.; McBride, M.; Yuan Z.; Zhang G.; Bredas J-L.; Reichmanis E. Synergistic Use of } \\
\text { Bithiazole and Pyridinyl Substitution for Effective Electron Transport Polymer Materials. Chem. Mater. 2019, } \\
\text { XXXX, XXX, XXX-XXX. }\end{array}$ \\
\hline
\end{tabular}




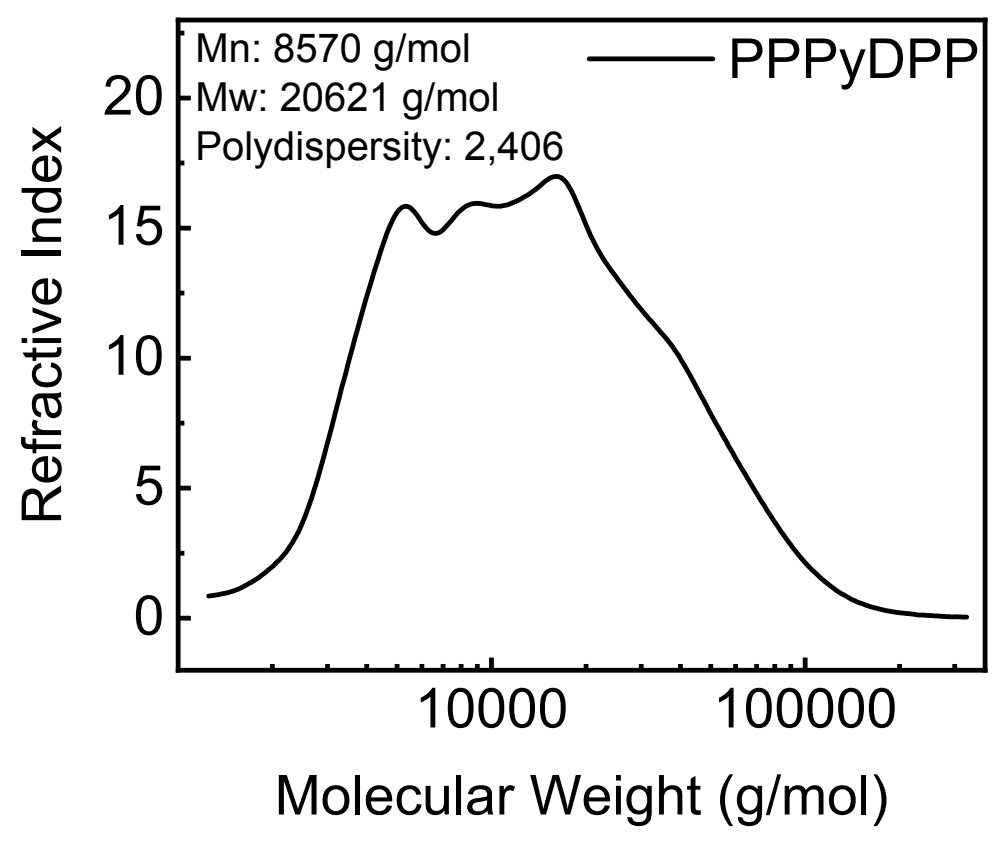

Figure S1. GPC analysis of PPPyDPP in THF

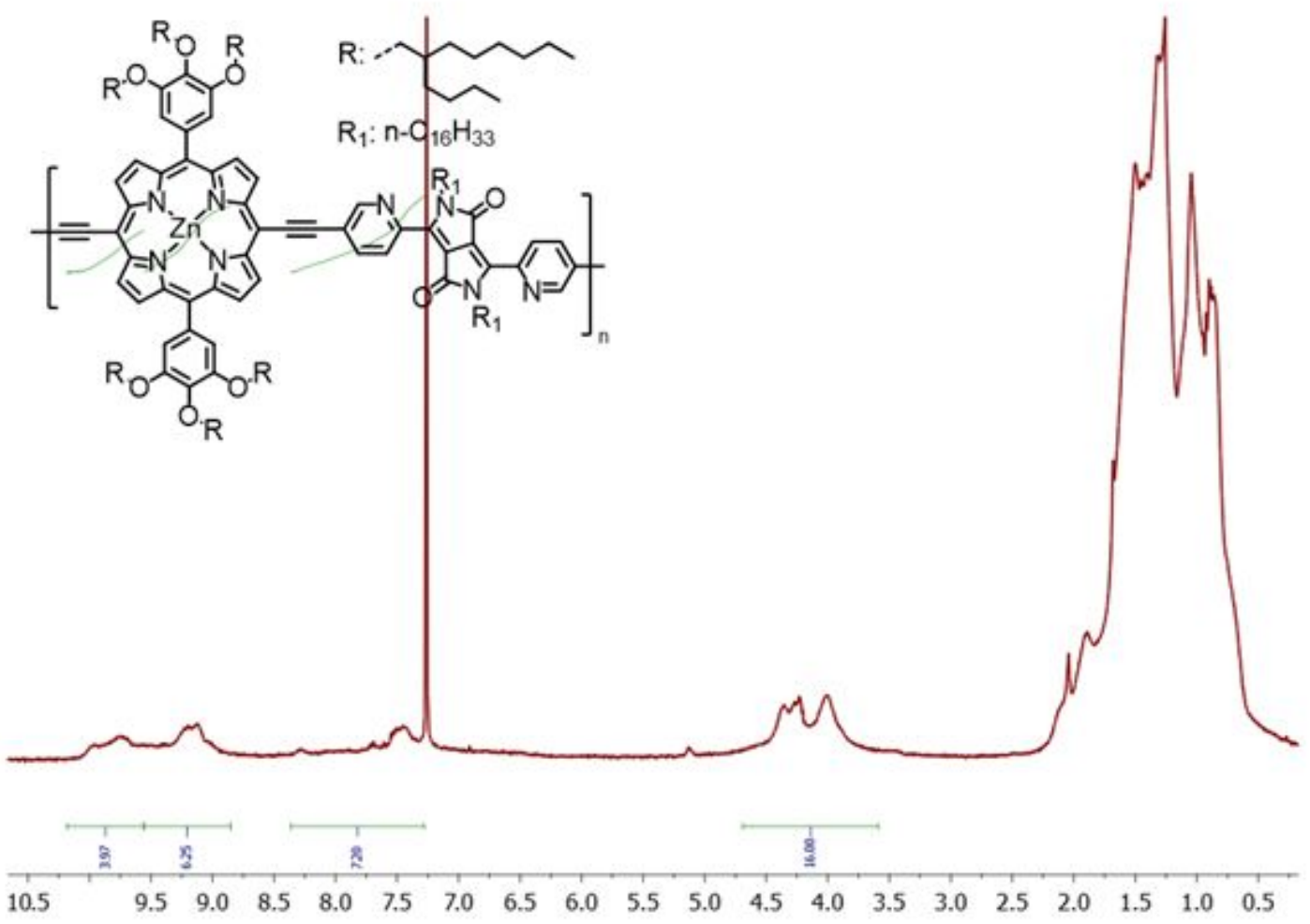

Figure S2. ${ }^{1} \mathrm{H}$ NMR of PPPyDPP in $\mathrm{CDCl}_{3}$ 

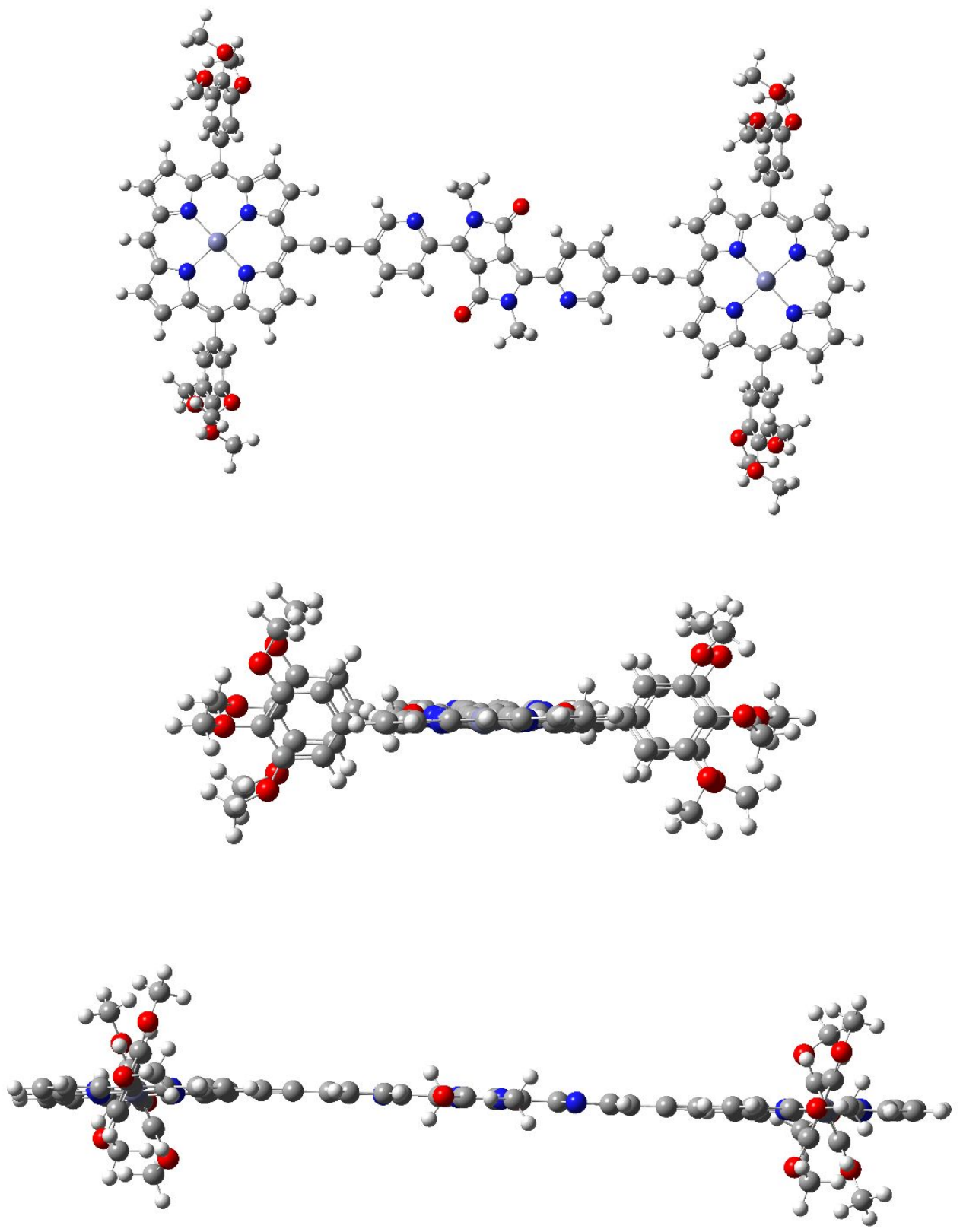

Figure S3. Geometry optimization of PPyP (by DFT) using a THF solvent field. 


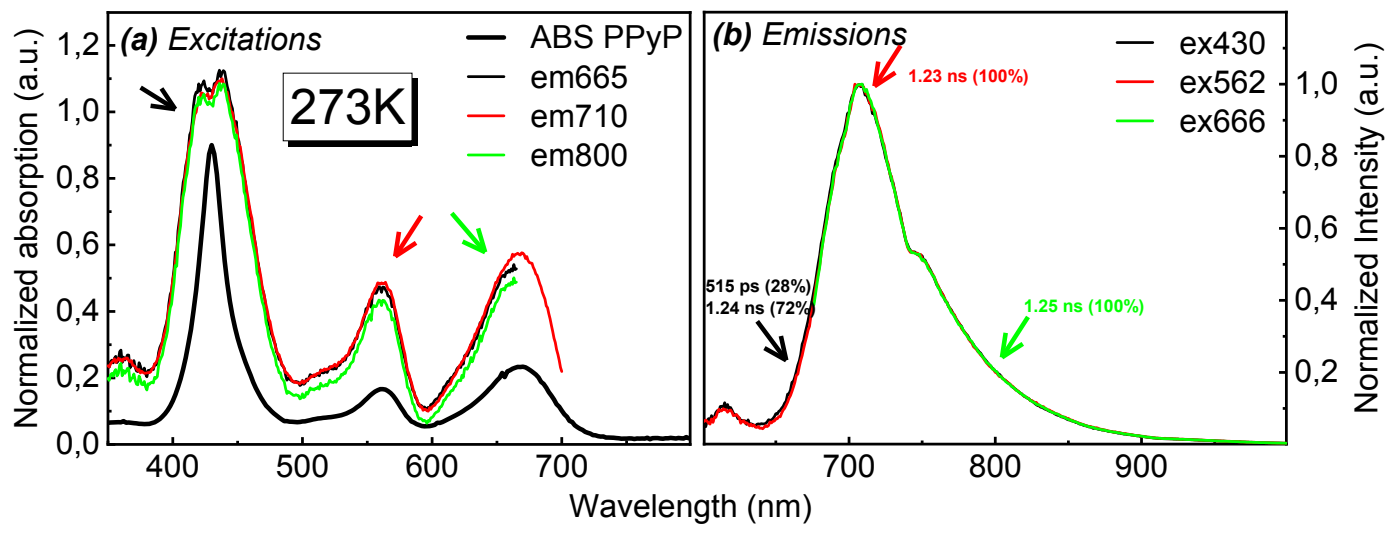

Figure S4. Normalized excitations spectra of PPyP in 2-MeTHF at 273K monitored from three emission wavelengths (a) and normalized emissions spectra using three different excitations shown in (b).
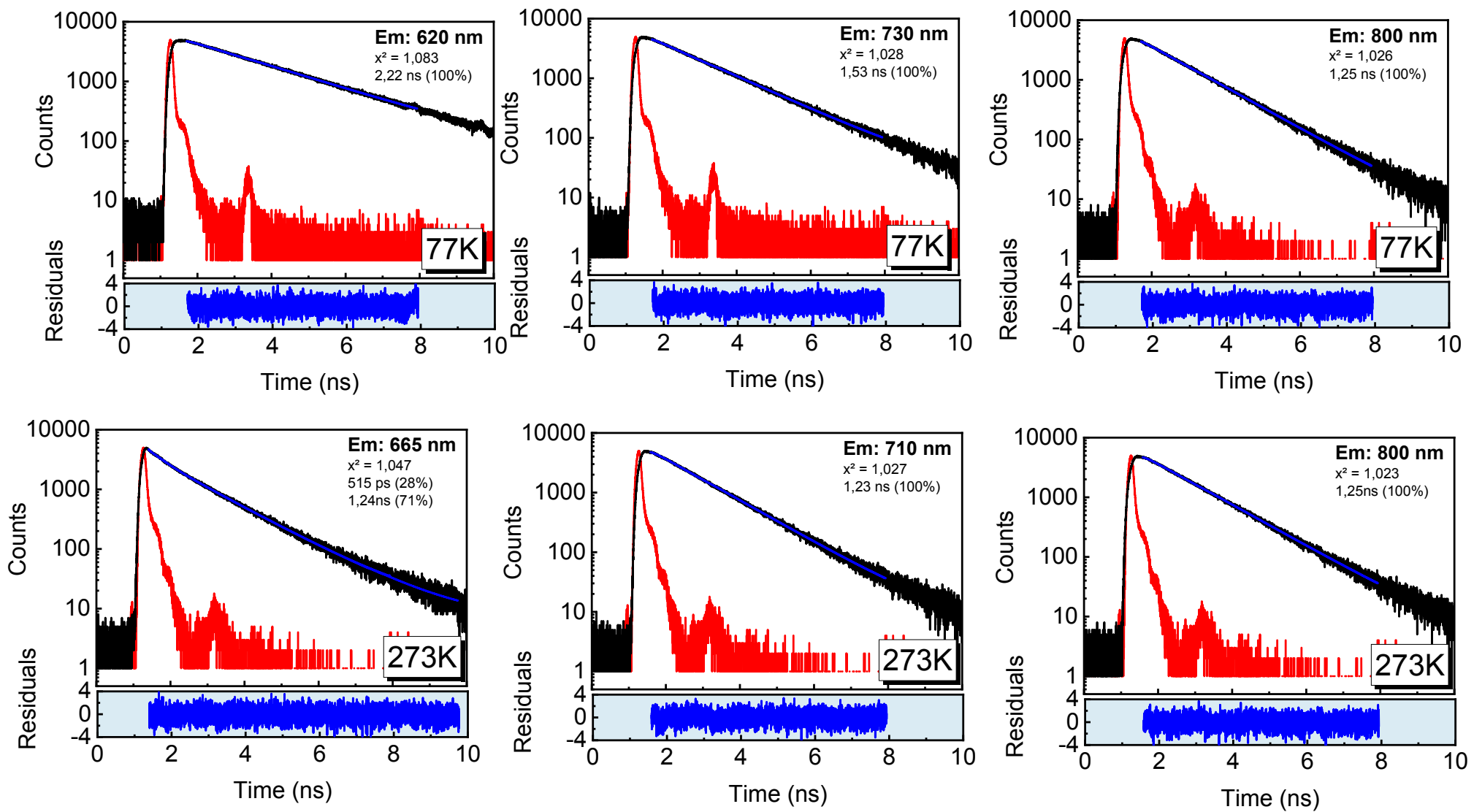

Figure S5. Fluorescence decay traces using $\lambda_{\mathrm{exc}}=443 \mathrm{~nm}$ of PPyP at $77 \mathrm{~K}$ in $2-\mathrm{MeTHF}$ recorded at 620, 730 and $800 \mathrm{~nm}$. Fluorescence decay traces using $\lambda_{\text {exc }}=443 \mathrm{~nm}$ of PPyP at $273 \mathrm{~K}$ in $2-\mathrm{MeTHF}$ recorded at 665,710 and $800 \mathrm{~nm}$. 


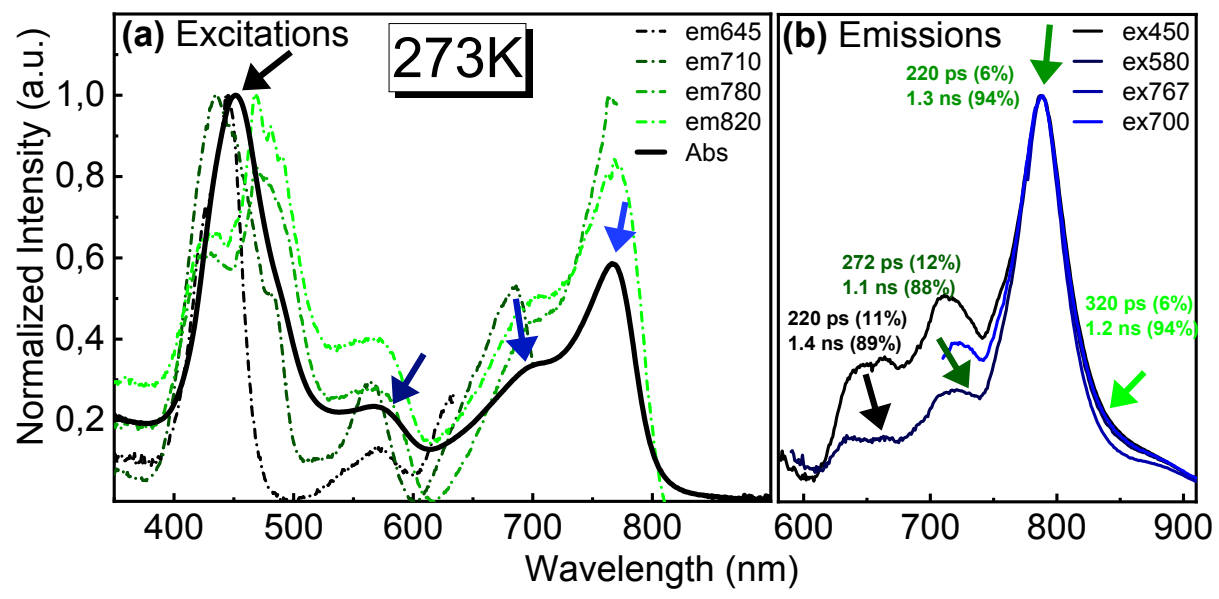

Figure S6. Normalized excitations spectra of PPPyDPP in 2-MeTHF at 273K monitored from four emission wavelengths (a) and normalized emissions spectra using four different excitations shown in (b).
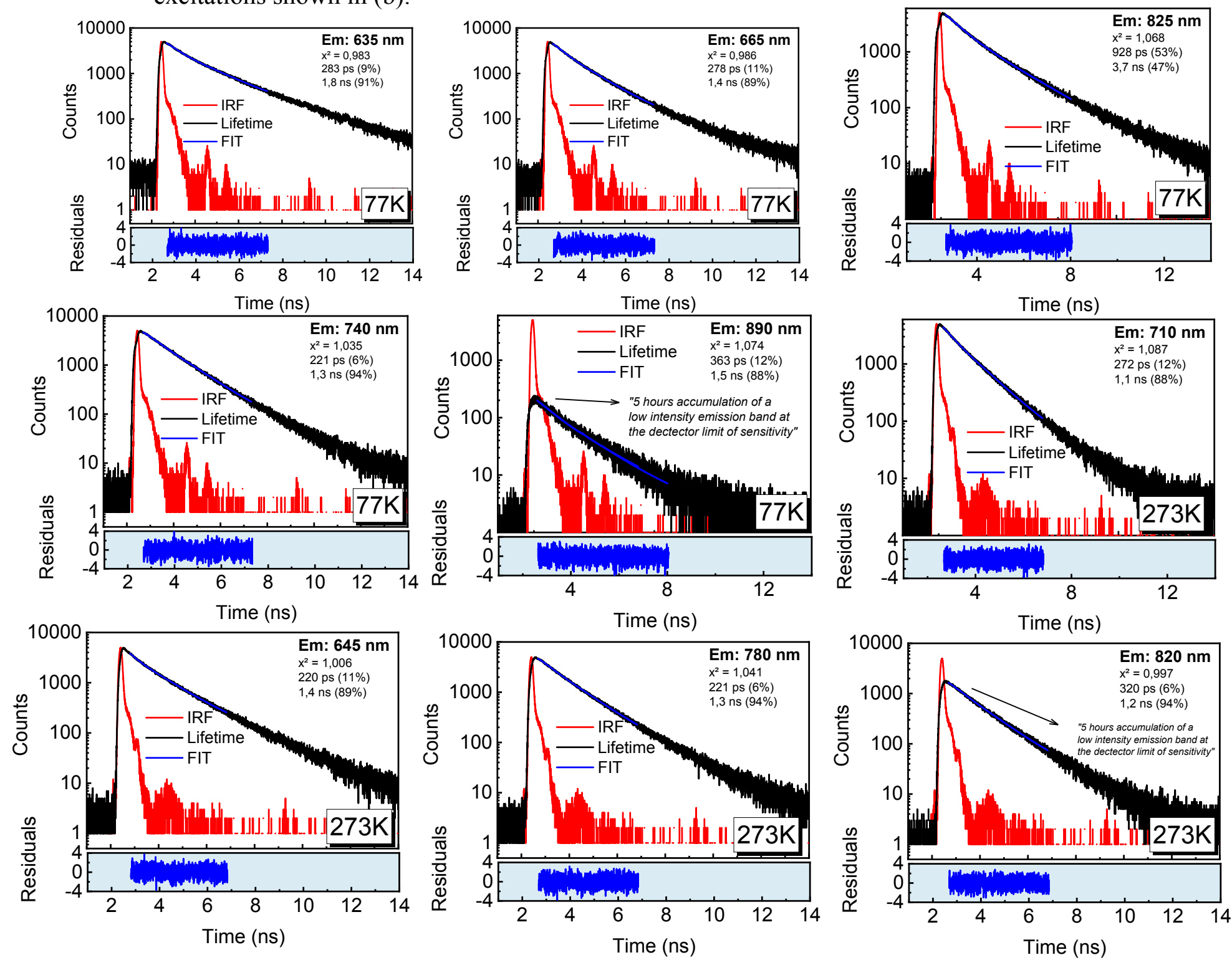

Figure S7. Fluorescence decay traces using $\lambda_{\text {exc }}=443 \mathrm{~nm}$ of PPPyDPP at $77 \mathrm{~K}$ in 2MeTHF recorded at $635,665,740,825$ and $890 \mathrm{~nm}$. Fluorescence decay traces using $\lambda_{\text {exc }}$ $=443 \mathrm{~nm}$ of PPPyDPP at 273K in 2-MeTHF recorded at 645, 710, 780 and $820 \mathrm{~nm}$. 


\section{Characterization}

All cyclic voltammetry measurements were performed using ferrocene as an internal standard vs Ag reference electrode. The pseudo electrode was a silver wire. A platinum electrode was used as working electrode and a platinum mesh as counter electrode. The potentials are reported vs the ferrocene/ferrocenium couple at $0 \mathrm{~V} \mathrm{vs} \mathrm{Fc} / \mathrm{Fc}^{0}$. Calculations of molecular orbital energy levels from cyclic voltammetry were performed according to these equations ${ }^{2}$ :

$$
\begin{aligned}
& \text { (1) HOMO }(\text { or LUMO })=-\left(E_{\text {pmean }}+4.8\right)(\mathrm{eV}) \\
& \text { (2) } E_{\text {pimean }}=\left(\frac{E_{p a i}+E_{p c i}}{2}\right)
\end{aligned}
$$

where $E_{\text {pai }}$ and $E_{p c i}$ stands for the anodic and cathodic electrical potential peak i corrected vs $\mathrm{Fc}^{+} / \mathrm{Fc} .4 .8 \mathrm{eV}$ was used as the HOMO energy level of ferrocene ${ }^{3}$.

PPPyDPP was drop casted on top of the platinum electrode. The measurements were performed using a $10^{-1} \mathrm{M}$ tetrabutylammonium hexafluorophosphate in an acetonitrile solution. The first oxidation peak is at $0.476 \mathrm{~V}$ corresponding to the $(\operatorname{PPPyDPP}(0) \rightarrow$ PPPyDPP $(+\mathrm{I})$ ) transition and the second one is at $0.929 \mathrm{~V}$ corresponding to the $(\mathrm{PPPyDPP}(0) \rightarrow$ PPPyDPP $(+\mathrm{II}))$ process. These two oxidations are irreversible and placed the HOMO at -5.27 and HOMO-1 at $-5.73 \mathrm{eV}$. The first reduction peak corresponds to $(\operatorname{PPPyDPP}(0) \rightarrow$ PPPYDPP(-I)) and is placed at $-1.016 \mathrm{~V}$ giving a LUMO at $-3.78 \mathrm{eV}$. The values are below that for the HOMO and LUMO manifolds reported for PPDPP (respectively -5.32 and $-3.87 \mathrm{eV}$ ) ${ }^{4}$ which is consistent with the generally observed decrease in HOMO and LUMO energy levels depicted for PyDPP-based molecules ${ }^{5}$. However, because the reduction peaks for these two electrochemical processes were not localized with precision, only an underestimation of the true MO energy could be possible. 


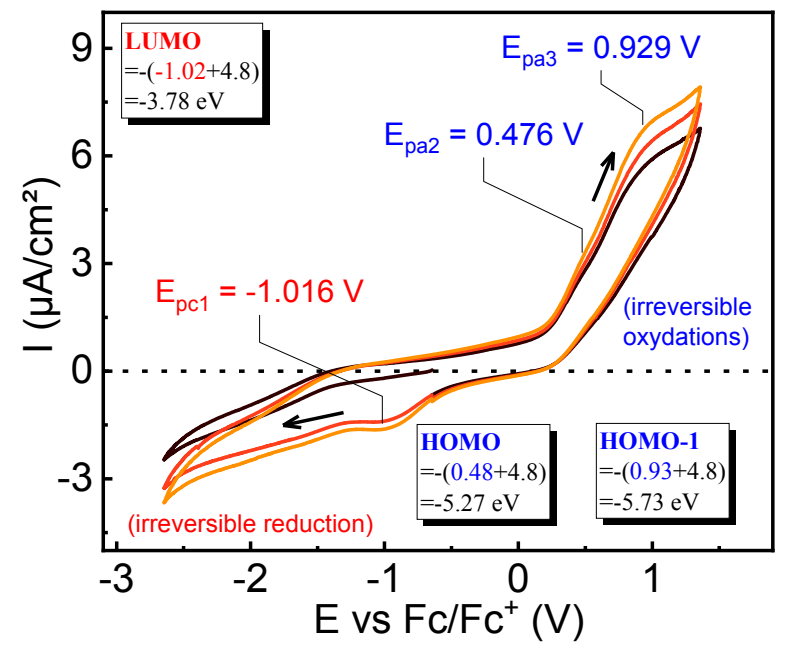

Figure S8. Cyclic voltammogram of PPPyDPP measured at $200 \mathrm{mV} / \mathrm{s}$ in acetonitrile. Detailed calculations of the HOMO, LUMO and $\mathrm{E}_{\text {gap }}$ are given inside insets.

The cyclic voltammogram of PPyP $\left(5.10^{-4} \mathrm{M}\right)$ was measured in a solution of $10^{-1} \mathrm{M}$ tetrabutylammonium hexafluorophosphate in dichloromethane. The oxidation peak at $0.509 \mathrm{~V}$ corresponds to the irreversible $(\mathrm{PPyP}(0) \rightarrow \mathrm{PPyP}(+\mathrm{I}))$ process placing the HOMO energy level of $-5.31 \mathrm{eV}$. The first reduction $(\mathrm{PPyP}(0) \rightarrow \mathrm{PPyP}(-\mathrm{I}))$ peak is found at $\mathrm{E}_{\mathrm{p} 2 \text { mean }}$ of $-1.39 \mathrm{~V}\left(\mathrm{E}_{\mathrm{pa} 2} / 2+\mathrm{E}_{\mathrm{pc} 2} / 2\right)$ corresponding to a LUMO level of $-3.40 \mathrm{eV}$. The second reduction peak $(\mathrm{PPyP}(0) \rightarrow \mathrm{PPyP}(-\mathrm{II}))$ is found at $\mathrm{E}_{\mathrm{p} 1 \text { mean }}$ of $-1.71 \mathrm{~V}\left(\mathrm{E}_{\mathrm{pa} 1} / 2+\mathrm{E}_{\mathrm{pc} 1} / 2\right)$ corresponding to a $\mathrm{LUMO}+1$ energy level of $3.09 \mathrm{eV}$. These energy levels give a band gap of $1.91 \mathrm{eV}(\lambda=649 \mathrm{~nm})$, which is slightly overestimated due to the irreversible wave $(\mathrm{PPyP}(0) \rightarrow \mathrm{PPyP}(+\mathrm{I}))$ which is in good agreement with the optical band gap $\left(\lambda_{\text {opt }}=692\right.$ $\mathrm{nm})$ obtained from the intersection of the normalized absorption and emission spectra of PPyP. HOMO energy level of PPyP and PPPyDPP are similar, however the LUMO level of PPyP of $-3.40 \mathrm{eV}$ is $0.38 \mathrm{eV}$ higher than that for its related polymer. These changes in LUMO levels are attributed to the lower content of PyDPP in PPyP. Indeed, PyDPP is known to decrease LUMO energy level ${ }^{5}$. 


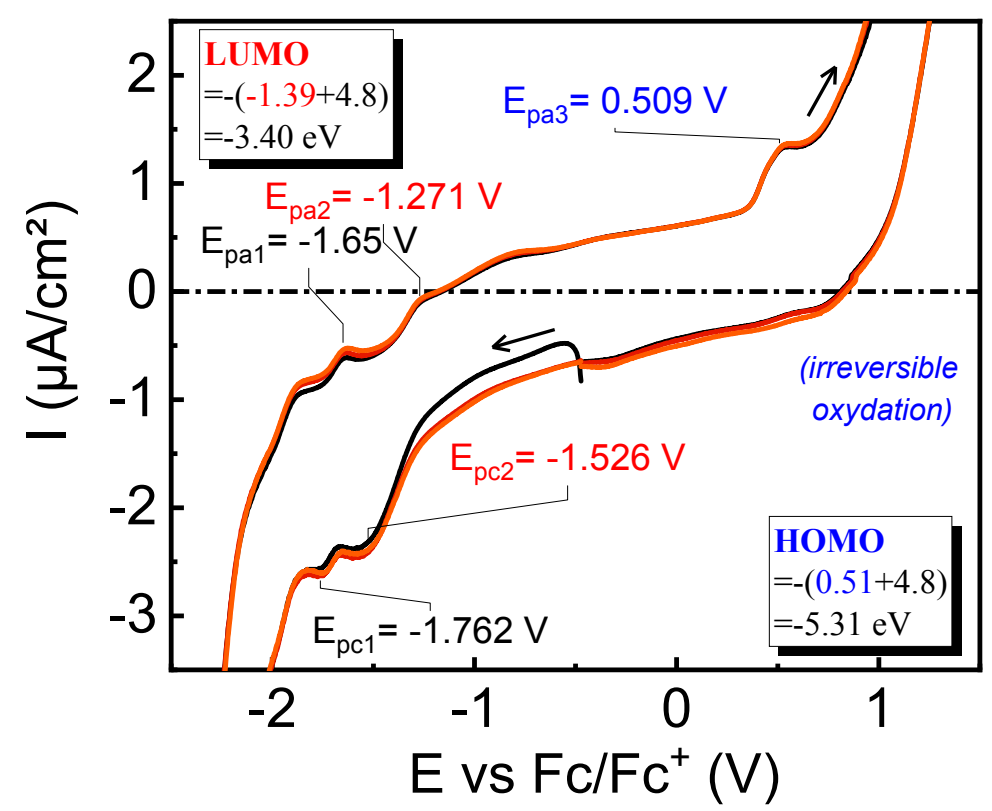

Figure S9. Cyclic voltammogram of PPyP measured at $100 \mathrm{mV} / \mathrm{s}$ in dichloromethane. Detailed calculations of the HOMO and LUMO levels, and $\mathrm{E}_{\text {gap }}$ are given inside insets.

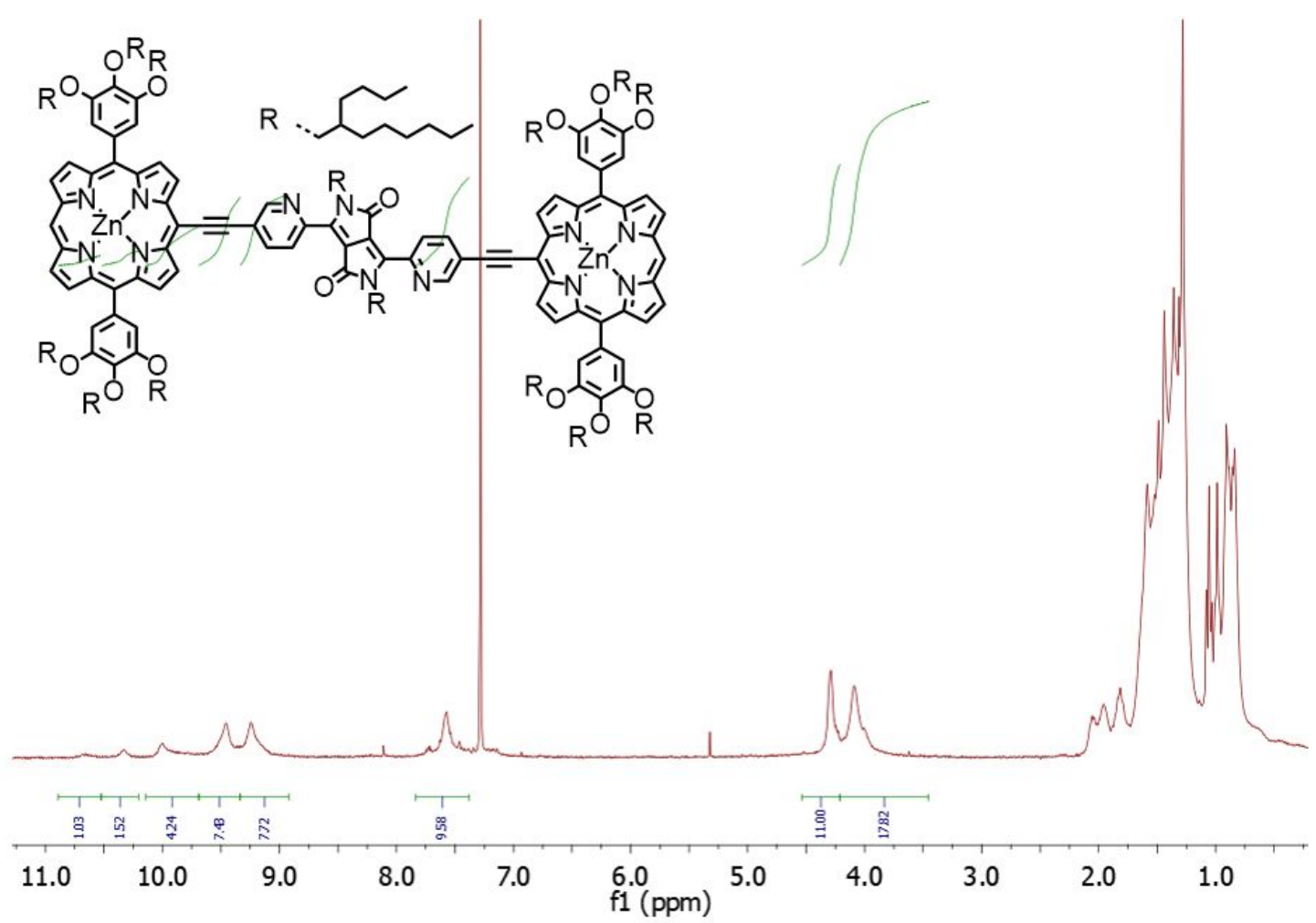

Figure S10. ${ }^{1} \mathrm{H}$ NMR spectrum of PPyP in $\mathrm{CDCl}_{3}$. Aromatics peaks position, integration and shaped are inexact due to Pyridin-Zn porphyrin interactions in solution. 

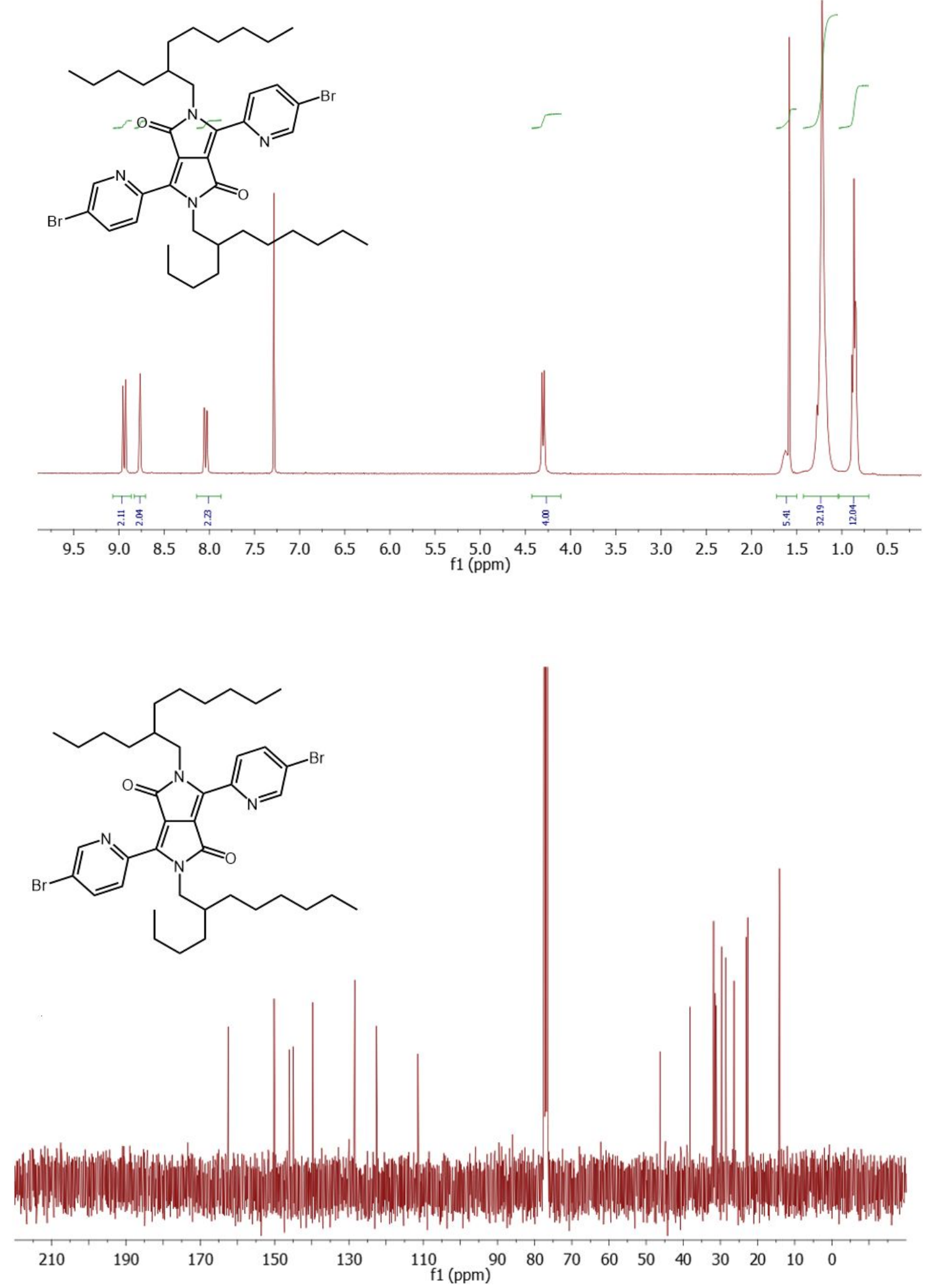

Figure S11. ${ }^{1} \mathrm{H}$ (top) and ${ }^{13} \mathrm{C}$ NMR (bottom) spectra of Br-PyDPP in $\mathrm{CDCl}_{3}$ 


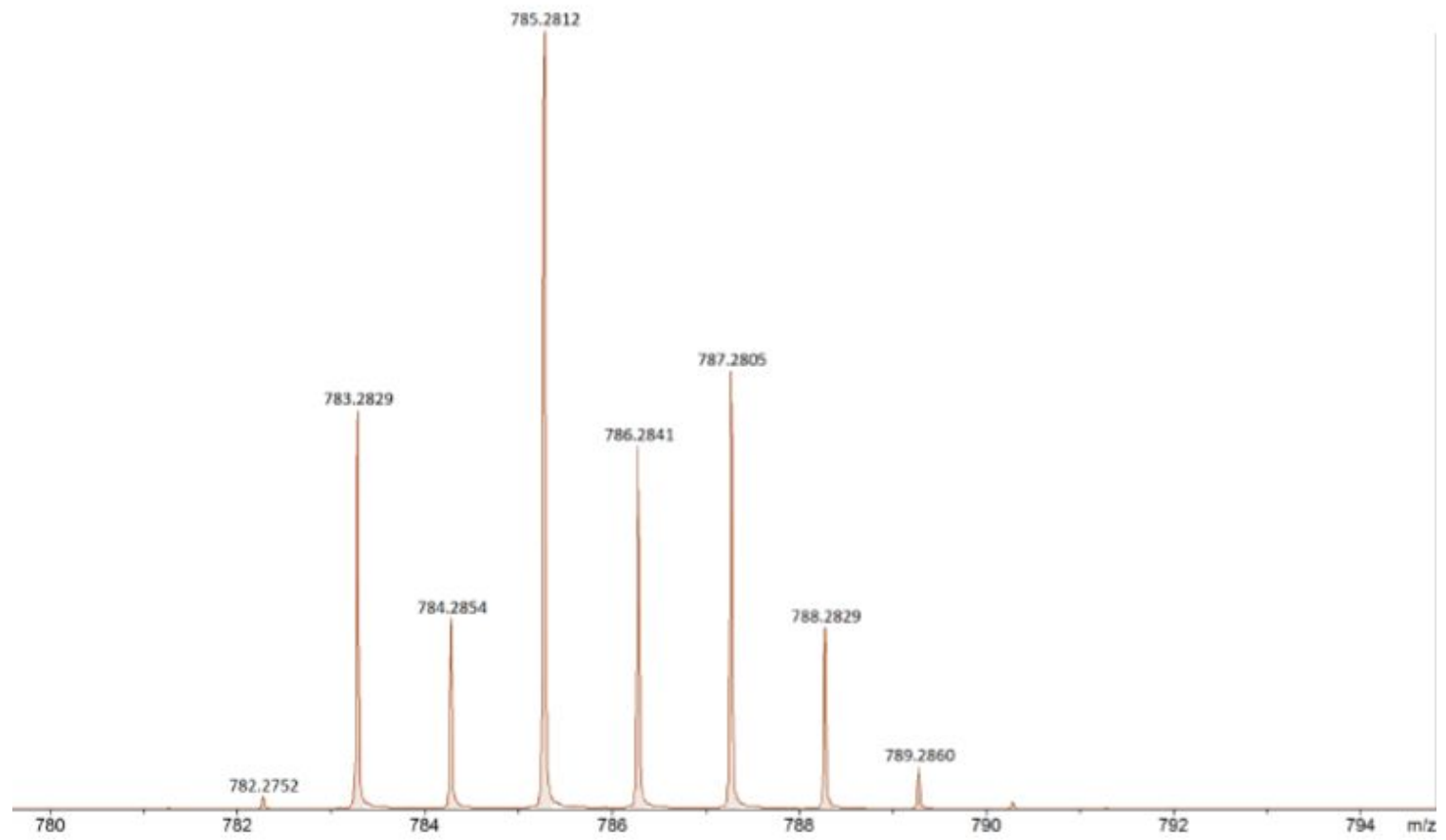

Figure S12. High resolution ESI+ of Br-PyDPP

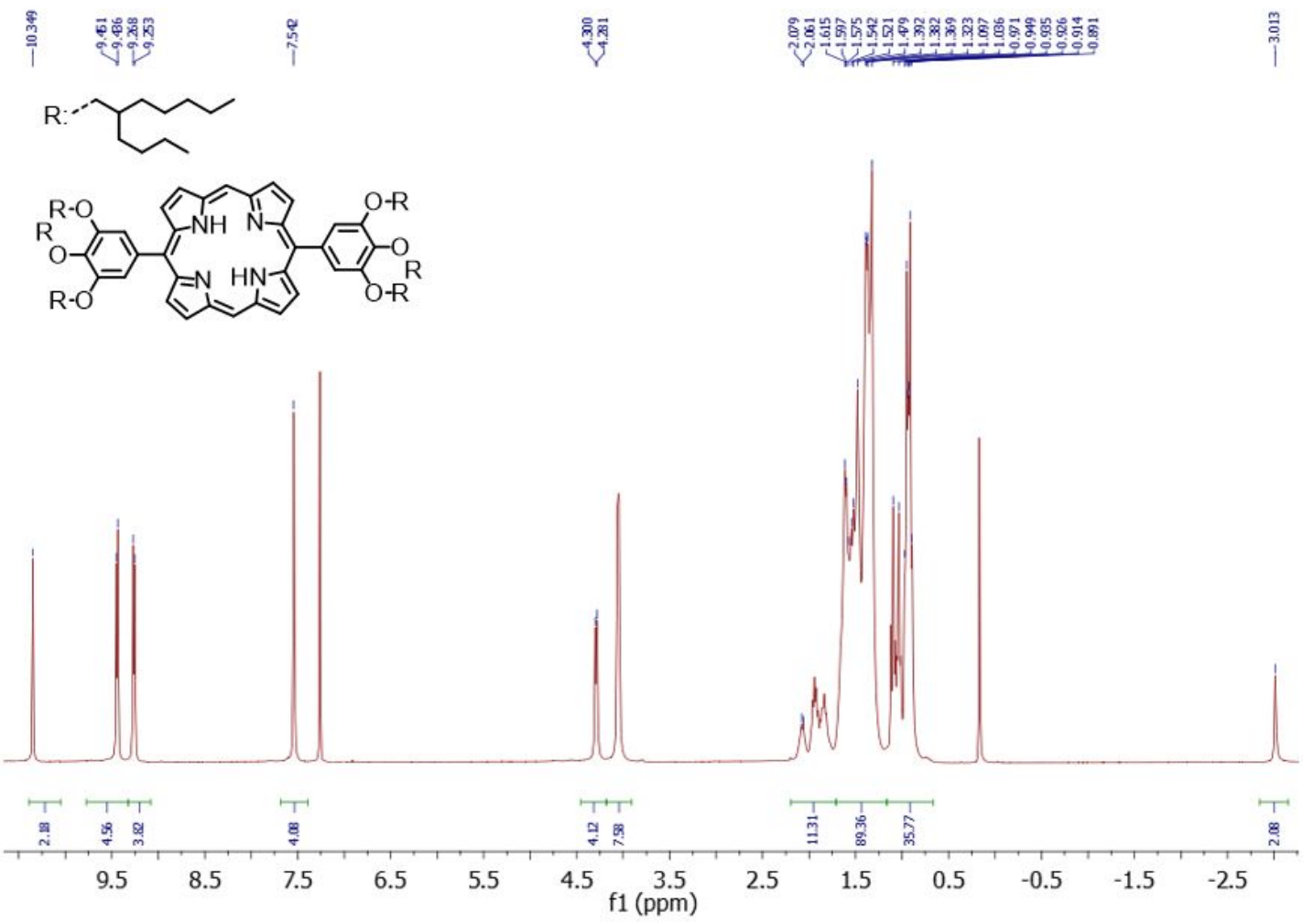

Figure S13. ${ }^{1} \mathrm{H}$ NMR spectrum of zinc(II)(5,15-bis[3,4,5-tris(2-butyloctyloxy)phenyl]10,20-porphyrinate in $\mathrm{CDCl}_{3}$ 


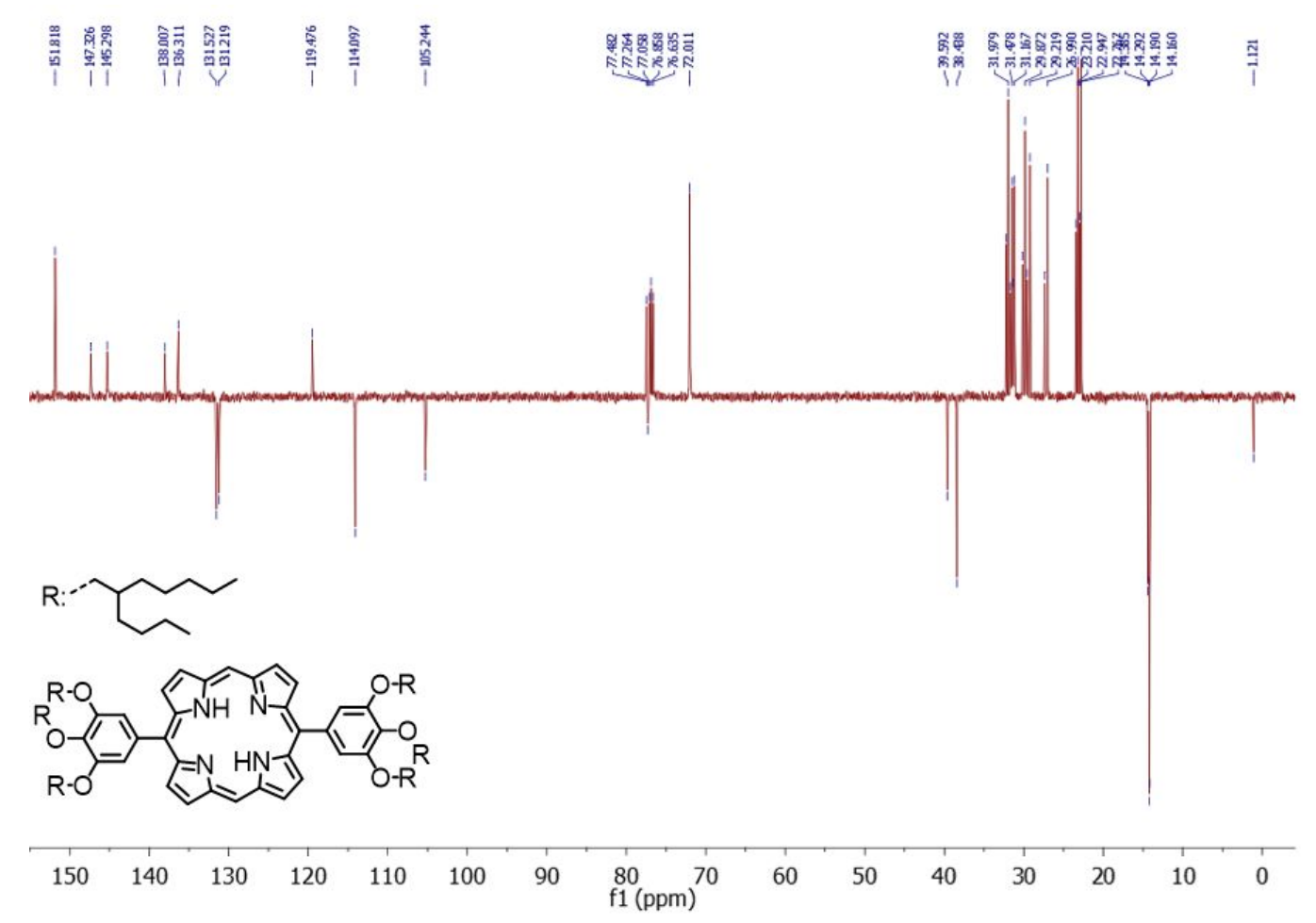

Figure S14. ${ }^{13} \mathrm{C}$ NMR (DEPT135) analysis of zinc(II)(5,15-bis [3,4,5-tris(2butyloctyloxy)phenyl]-10,20-porphyrinate in $\mathrm{CDCl}_{3}$

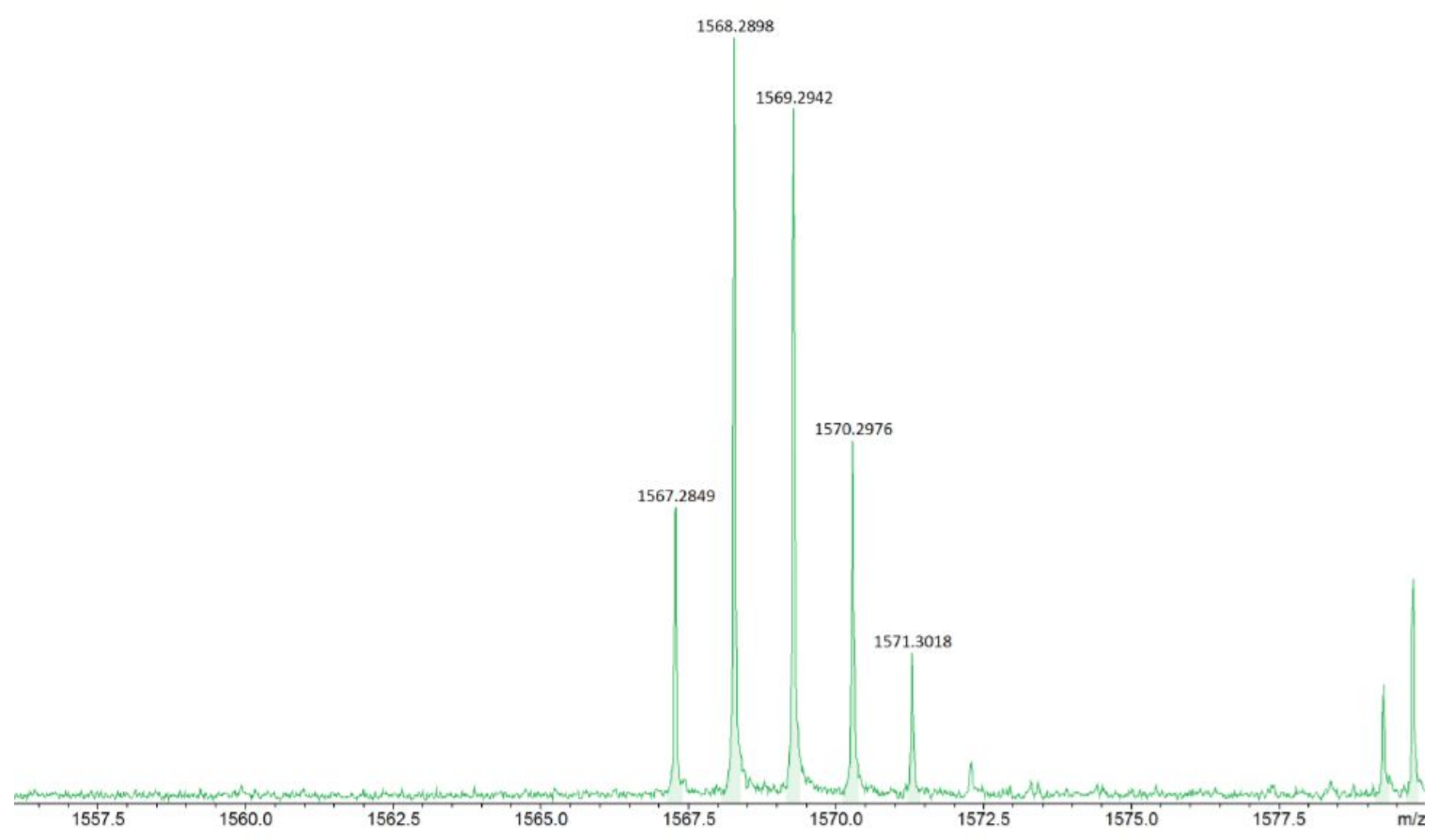

Figure S15. High resolution ESI+ of zinc(II)(5,15-bis[3,4,5-tris(2butyloctyloxy)phenyl]-10,20-porphyrinate 


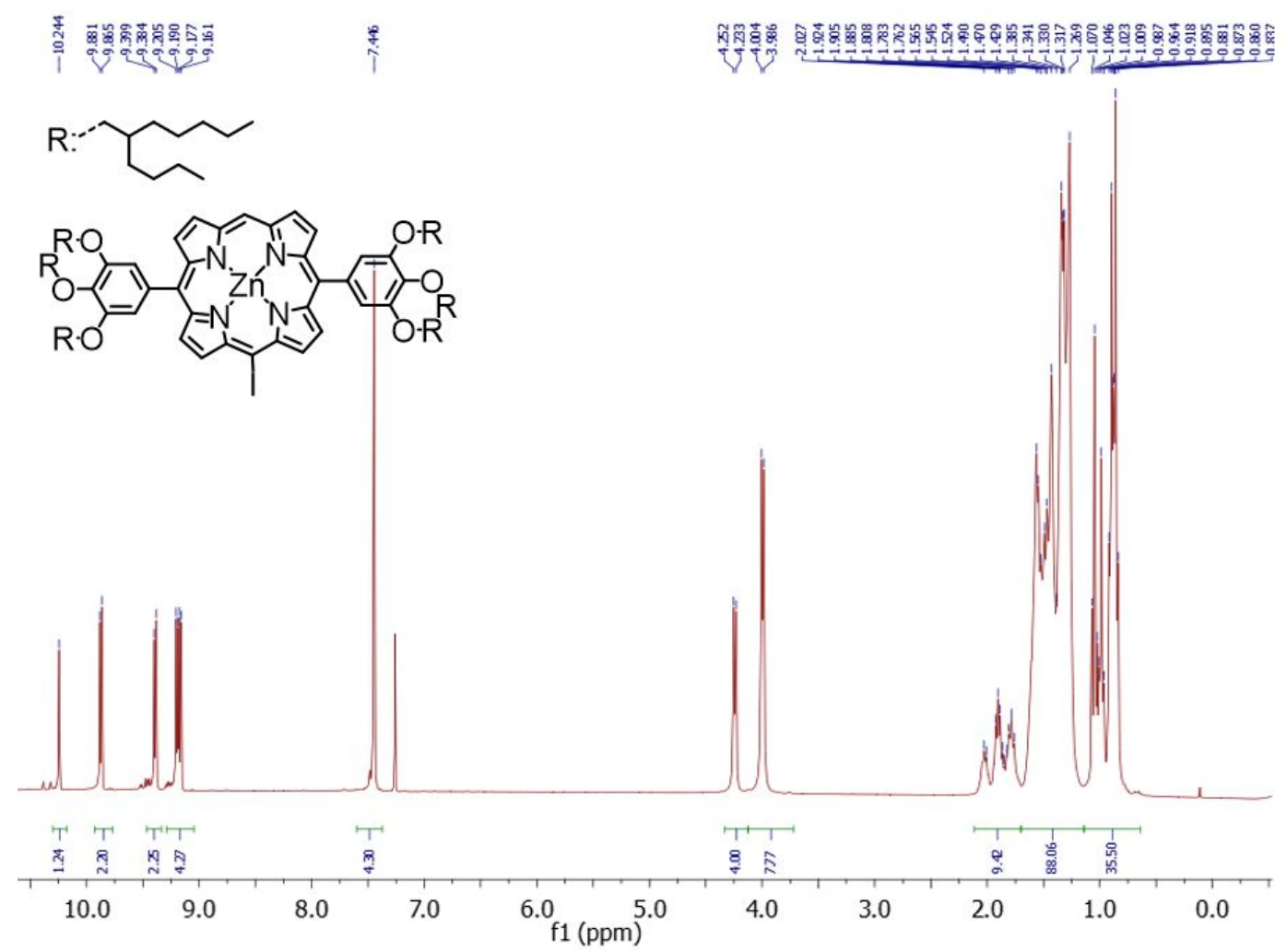

Figure S16. ${ }^{1} \mathrm{H}$ NMR spectrum of zinc(II)(10-iodo-5,15-bis[3,4,5-tris(2butyloctyloxy)phenyl]-20-porphyrinate in $\mathrm{CDCl}_{3}$
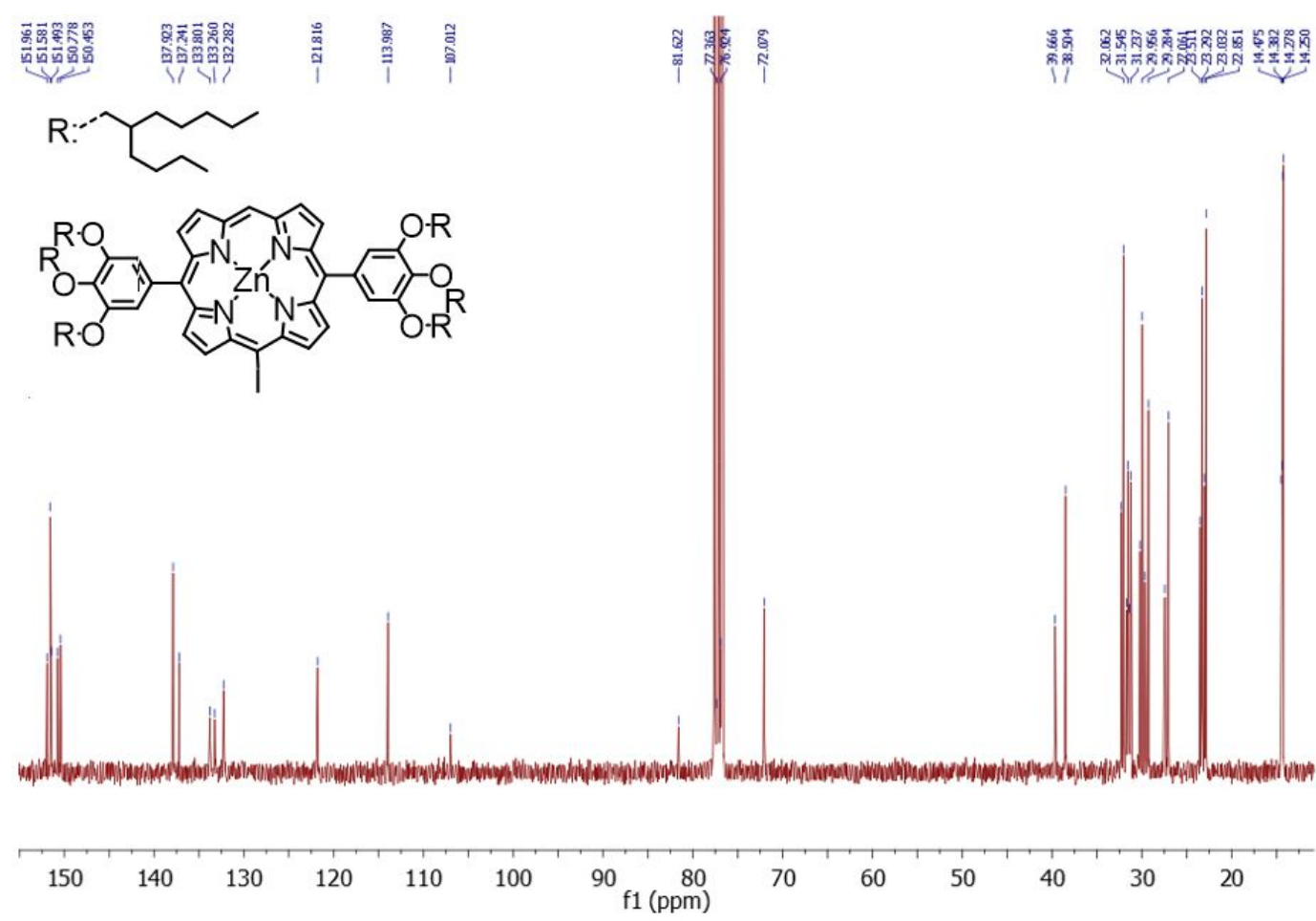

Figure S17. ${ }^{13} \mathrm{C}$ NMR spectrum of zinc(II)(10-iodo-5,15-bis[3,4,5-tris(2butyloctyloxy)phenyl]-20-porphyrinate in $\mathrm{CDCl}_{3}$ 


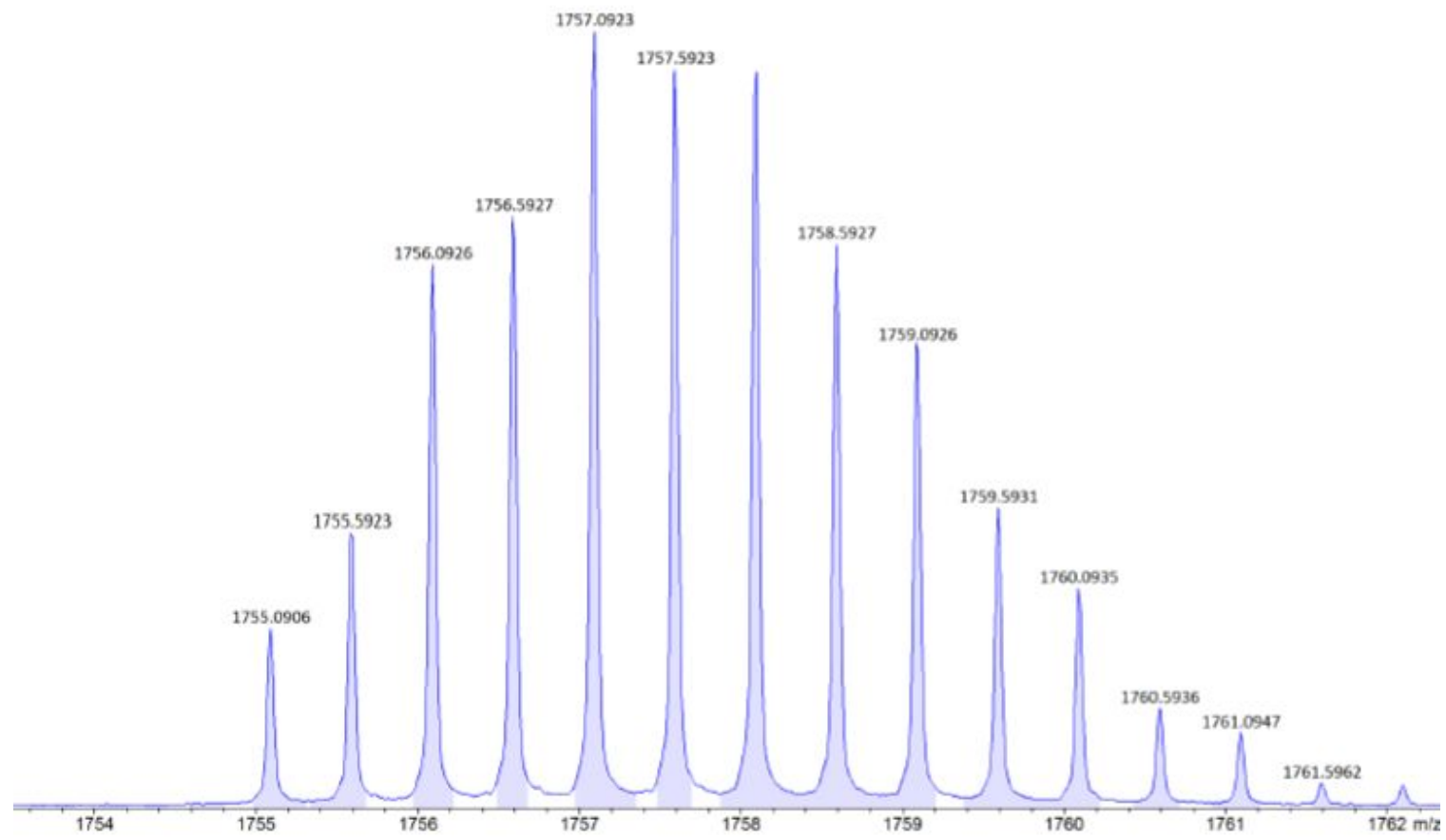

Figure S18. High resolution ESI+ of zinc(II)(10-iodo-5,15-bis[3,4,5-tris(2butyloctyloxy)phenyl]-20-porphyrinate

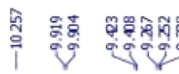

$\stackrel{\substack{4 \\ \uparrow}}{\uparrow}$

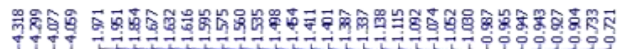

R:

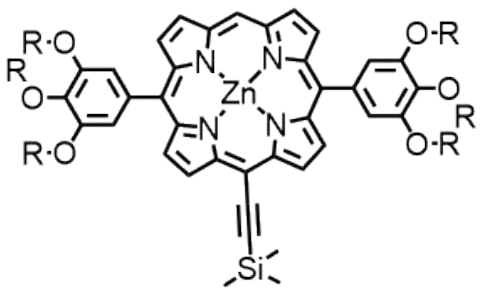

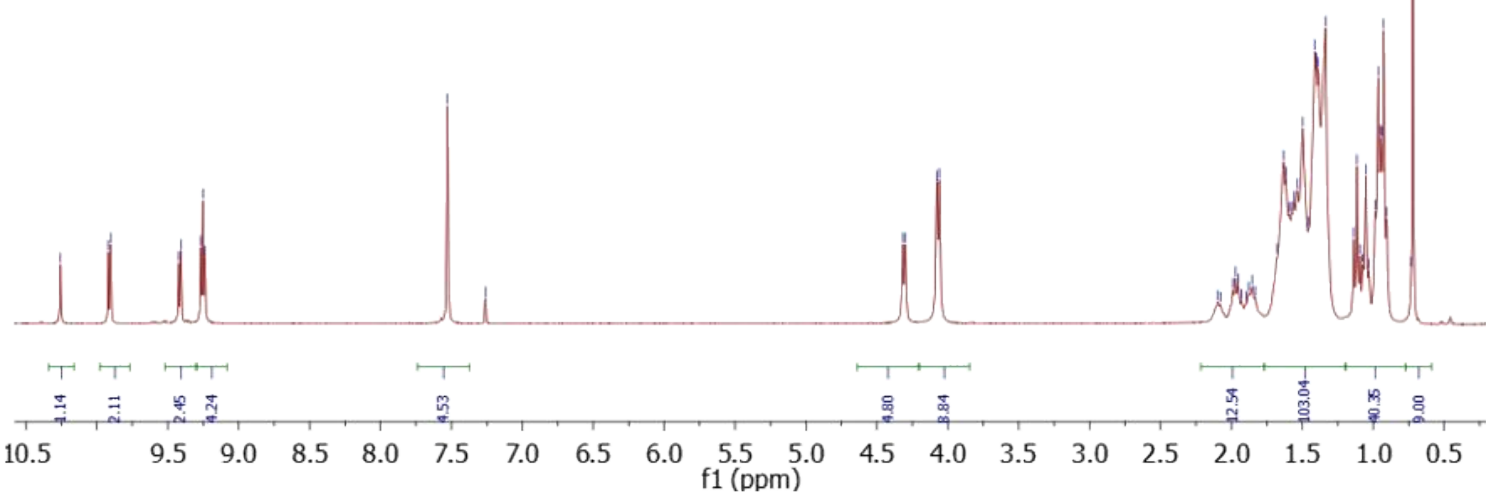

Figure S19. ${ }^{1} \mathrm{H}$ NMR spectrum of zinc(II)(10-[(trimethylsilyl)ethynyl]-5,15-bis[3,4,5tris(2-butyloctyloxy)phenyl]-20-porphyrinate in $\mathrm{CDCl}_{3}$ 


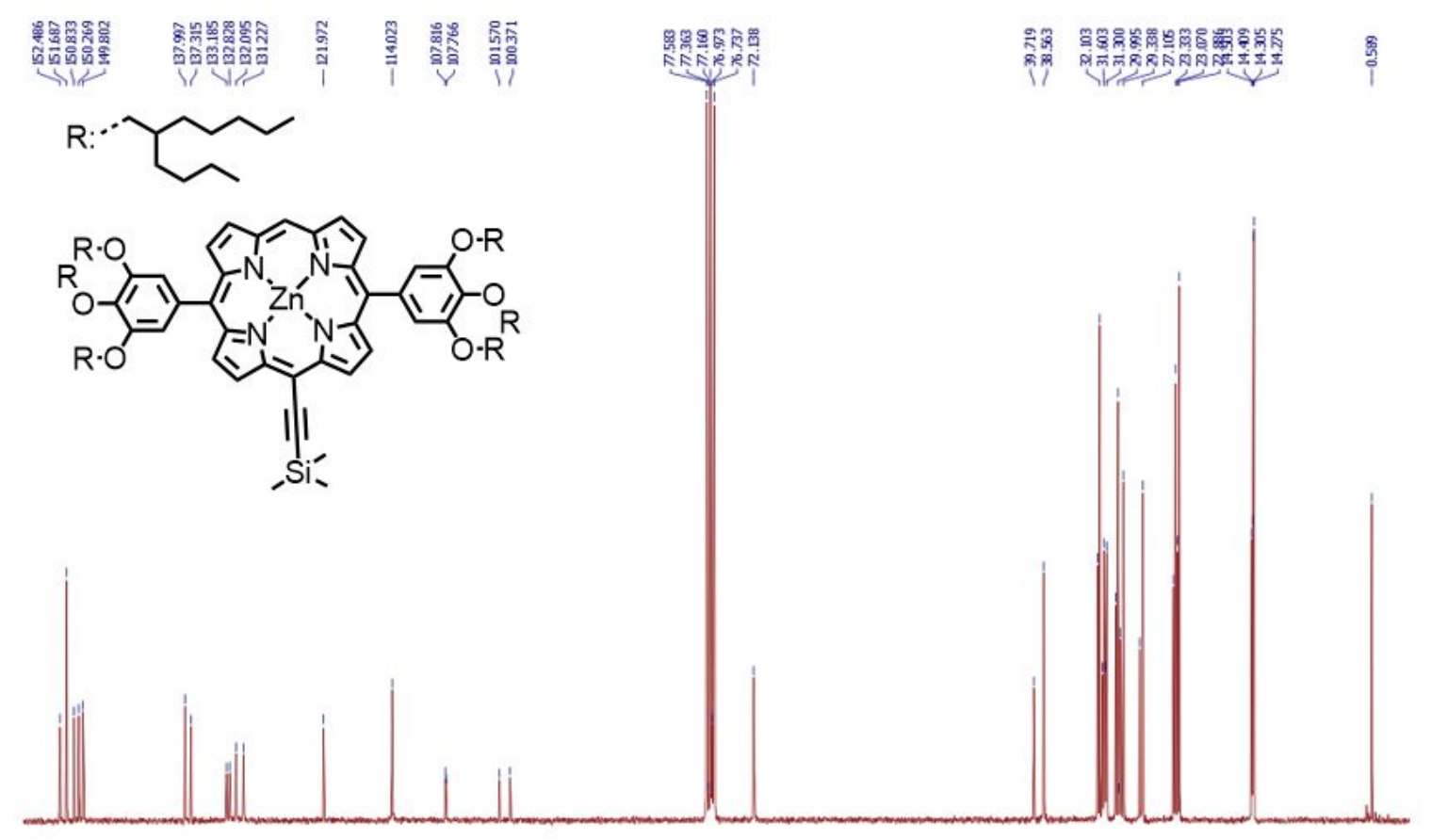

\begin{tabular}{|c|c|c|c|c|c|c|c|c|c|c|c|c|c|c|}
\hline 150 & 140 & 130 & 120 & 110 & 100 & 90 & $\begin{array}{l}80 \\
\mathrm{f} 1(\mathrm{ppm})\end{array}$ & 60 & 50 & 40 & 30 & 20 & 10 & 0 \\
\hline
\end{tabular}

Figure S20. ${ }^{13} \mathrm{C}$ NMR analysis of zinc(II)(10-[(trimethylsilyl)ethynyl]-5,15-bis[3,4,5tris(2-butyloctyloxy)phenyl]-20-porphyrinate in $\mathrm{CDCl}_{3}$

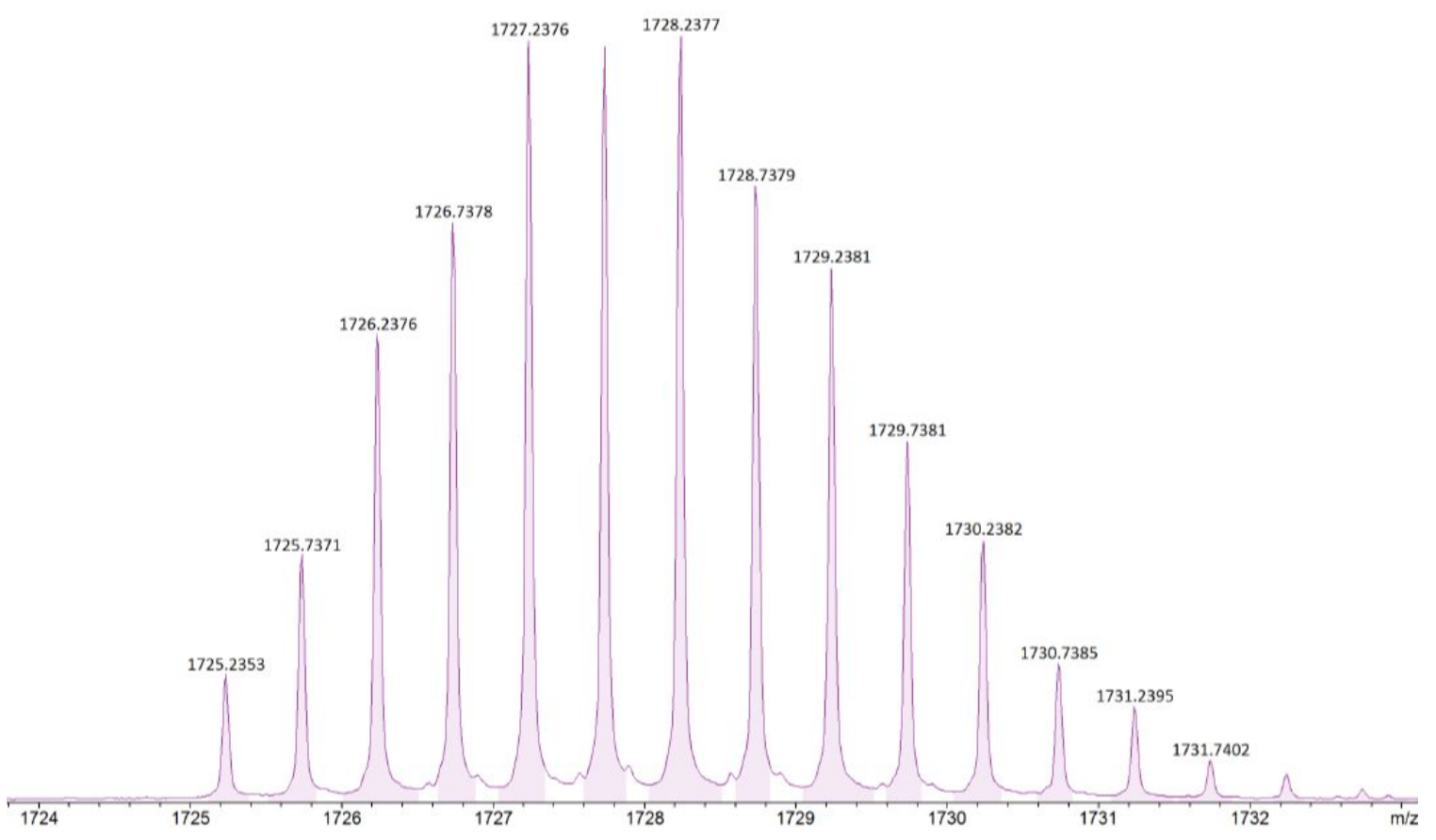

Figure S21. High resolution ESI+ of zinc(II)(10-iodo-5,15-bis[3,4,5-tris(2butyloctyloxy)phenyl]-20-porphyrinate 


\section{References}

(1) Gagne, R. R.; Koval, C. A.; Lisensky, G. C. Ferrocene as an Internal Standard for Electrochemical Measurements. Inorg. Chem. 1980, 19 (9), 2854-2855. https://doi.org/10.1021/ic50211a080.

(2) Cardona, C. M.; Li, W.; Kaifer, A. E.; Stockdale, D.; Bazan, G. C. Electrochemical Considerations for Determining Absolute Frontier Orbital Energy Levels of Conjugated Polymers for Solar Cell Applications. Adv. Mater. 2011, 23 (20), 2367-2371. https://doi.org/10.1002/adma.201004554.

(3) D’Andrade, B. W.; Datta, S.; Forrest, S. R.; Djurovich, P.; Polikarpov, E.; Thompson, M. E. Relationship between the Ionization and Oxidation Potentials of Molecular Organic Semiconductors. Org. Electron. physics, Mater. Appl. 2005, 6 (1), 11-20. https://doi.org/10.1016/j.orgel.2005.01.002.

(4) Bucher, L.; Tanguy, L.; Fortin, D.; Desbois, N.; Harvey, P. D.; Sharma, G. D.; Gros, C. P. A Very Low Band Gap Diketopyrrolopyrrole-Porphyrin Conjugated Polymer. Chempluschem 2017, 82 (4), 625-630. https://doi.org/10.1002/cplu.201700035.

(5) Sun, B.; Hong, W.; Aziz, H.; Li, Y. A Pyridine-Flanked Diketopyrrolopyrrole (DPP)-Based Donor-Acceptor Polymer Showing High Mobility in Ambipolar and n-Channel Organic Thin Film Transistors. Polym. Chem. 2015, 6 (6), 938-945. https://doi.org/10.1039/C4PY01193G. 